\title{
STATE DRUG CONTROL SPENDING AND ILLICIT DRUG PARTICIPATION
}

\author{
Henry Saffer \\ Frank Chaloupka
}

Working Paper 7114

http://www.nber.org/papers/w7114

\author{
NATIONAL BUREAU OF ECONOMIC RESEARCH \\ 1050 Massachusetts Avenue \\ Cambridge, MA 02138 \\ May 1999
}

The authors would like to thank Dhaval Dave for research assistance and the participants at the Robert Wood Johnson Foundation annual meetings of the Substance Abuse Policy research program in 1998 and 1997 for helpful comments. This project was supported by a grant from the Robert Wood Johnson Foundation to the National Bureau of Economic Research. The views expressed herein are those of the authors and do not necessarily reflect the views of the National Bureau of Economic Research.

(C) 1999 by Henry Saffer and Frank Chaloupka. All rights reserved. Short sections of text, not to exceed two paragraphs, may be quoted without explicit permission provided that full credit, including (C) notice, is given to the source. 
State Drug Control Spending and Illicit Drug Participation

Henry Saffer and Frank Chaloupka

NBER Working Paper No. 7114

May 1999

JEL No.I1

\begin{abstract}
The purpose of this paper is to estimate the effect of state criminal justice expenditures and state public health expenditures on deterring illicit drug use. The empirical model is based on a demand and supply model of drug markets. The effect of a given expenditure on criminal justice or public health programs is dependent on the magnitude of the resulting shifts in the two functions and the demand price elasticity. A reduced form of the demand and supply model is also estimated. The data employed come from the 1990 and 1991 National Household Surveys on Drug Abuse (NHSDA). Data on state and local spending for drug related criminal justice and drug related public health programs were merged with the NHSDA. The main findings from the regression results are that drug control spending reduces drug use. However, the results suggest for marijuana users, the marginal cost of drug control exceeds the social benefits of drug control. This may not be the case for users of other illicit drugs. Spending for drug enforcement by police and drug treatment are found most effective in deterring drug use. However, spending for correctional facilities is never significant which suggests that a more efficient method of reducing drug use might be to reduce correctional facilities spending and increase spending on treatment.
\end{abstract}

Henry Saffer

NBER

50 East 42nd Street, 17th Floor

New York, NY 10017-5405

hsaffer@email.gc.cuny.edu
Frank Chaloupka

Department of Economics

College of Business Administration

University of Illinois

601 S. Morgan Street, Rm. 2103

Chicago, IL 60607-7121

and NBER

fjc@uic.edu 


\section{Introduction}

Illicit drugs impose significant costs on society and on the individual users. These costs include increased crime, health problems and employment problems. Because of these considerable costs, both the federal government and state governments have made drug control an important budget priority. According to the Office of National Drug Control Policy (ONDCP) 1995 , federal spending on drug control increased from $\$ 1.5$ billion in fiscal 1981 to $\$ 17.8$ billion in fiscal 1999. This is an annual growth rate of over 14 percent. Spending on criminal justice, interdiction and international programs has remained at about 60 to 70 percent of total drug control spending. State government drug control expenditures are also for both criminal justice programs and public health programs. Criminal justice programs include the enforcement of laws pertaining to the use and sale of illicit drugs through expenditures on police, courts, prosecution, and corrections. Public health programs include expenditures on drug education and treatment. In addition, government must provide for the defense of individuals who are unable to provide their own defense. Although the available data on state and local level spending are limited to 1990 and 1991, these expenditures have probably also grown over time. In 1991, state and local governments spent $\$ 15.8$ billion on drug control (ONDCP, 1993). Spending on criminal justice was about 80 percent of total state and local spending on drug control. The purpose of this paper is to estimate the effects of state level expenditures on criminal justice and public health in reducing drug use.

To analyze the effects of criminal justice and public health spending, economists (i.e. Lee, 1993; Wagstaff, 1989) have employed a supply and demand model. This model assumes a demand function which is downward sloping with respect to price and a supply function which is horizontal or upward sloping with respect to price. Criminal justice spending directed at drug 
dealers may increase the cost of doing business which would raise the price of illicit drugs and reduce drug use. Criminal justice spending directed at users may shift the demand curve to the left which would reduce drug use and reduce drug prices. Public health programs inform potential buyers of the health risks associated with drug use and may also shift demand to the left, reducing drug prices and reducing drug use. Public health spending may affect supply since some users finance all or part of their consumption by selling drugs. Public health spending can reduce the number of these low level user-suppliers and thus reduce supply. The effect of a given expenditure on criminal justice or public health is dependent on the magnitude of the resulting shifts in the two functions and the supply and demand price elasticities. While the supply and demand model of drug markets is an important theoretical framework, there has been very little quantification of this model until recently. The new empirical research is limited to estimation of drug demand price elasticities. There is no empirical evidence concerning the effectiveness of expenditures of criminal justice spending and public health spending in shifting supply and demand functions and thus reducing drug use.

\section{Theoretical Model}

The empirical equations are derived from a supply and demand model of the illicit drug market. The most general specification of the model includes criminal justice and public health spending in both the demand curve and the supply curve. Public health spending may affect the demand curve since these expenditures are assumed to increase knowledge of the negative health consequences of drug use and thus reduce demand. Criminal justice spending may enter the demand function since some part of criminal justice expenditure goes to enforcing sanctions against users. Criminal justice enters the supply function since these programs increase costs. 
Public health spending may also enter the supply curve since many low level drug suppliers are also users and public health spending can reduce the number of these dealer-users. The demand curve can be written as:

$Q_{\mathrm{JJ}}=\beta_{1} \mathrm{P}_{\mathrm{J}}+\beta_{2} \mathrm{PH}_{\mathrm{J}}+\beta_{3} \mathrm{CJ}_{\mathrm{J}}+\beta_{4} \mathrm{Z}_{\mathrm{JJ}}+\mu_{\mathrm{IJQ}}$

and the supply curve can be written as:

$\mathrm{P}_{\mathrm{J}}=\delta_{1} \mathrm{PH}_{\mathrm{J}}+\delta_{2} \mathrm{CJ}_{\mathrm{J}}+\delta_{3} \mathrm{X}_{\mathrm{J}}+\mu_{\mathrm{JP}}$

where the $\mathrm{J}$ subscript refers to the $\mathrm{J}^{\text {th }}$ state and $\mathrm{Q}_{\mathrm{IJ}}=$ drug use by the $\mathrm{I}^{\text {th }}$ individual in the $\mathrm{J}^{\text {th }}$ state, $\mathrm{P}_{\mathrm{J}}=$ price in the $\mathrm{J}^{\text {th }}$ state, $\mathrm{PH}_{\mathrm{J}}=$ public health expenditures per capita in the $\mathrm{J}^{\text {th }}$ state, $\mathrm{CJ}_{\mathrm{J}}=$ criminal justice expenditures per capita in the $\mathrm{J}^{\text {th }}$ state, $\mathrm{Z}_{\mathrm{IJ}}=$ other demand factors for $\mathrm{I}^{\text {th }}$ individual in the $\mathrm{J}^{\text {th }}$ state, $\mathrm{X}_{\mathrm{J}}=$ other cost factors in the $\mathrm{J}^{\text {th }}$ state and the $\mu$ are disturbance terms.

The demand function (1) shows that the individual's demand for drugs is a function of drug price, public health expenditures, criminal justice expenditures, other demand factors and a disturbance term. The supply function (2) shows that price is a function of public health spending, criminal justice spending, other cost factors and a disturbance term. This supply function is infinitely elastic, since price is assumed to be primarily determined by expected penalties and independent of the market clearing quantity. Reuter (1988) argues that production and distribution costs have no significant influence on price but rather that prices are primarily determined by expected penalties. The effect of criminal justice spending and public health spending can be measured by estimating these two structural equations.

Criminal justice and public health spending can affect drug participation directly through deterrent, education and treatment effects but can also affect drug participation by raising drug prices. The structural demand model holds the effect of drug prices constant. A reduced form model can be defined which eliminates drug prices. Substitution of equation (2) into equation (1) 
results in the reduced form equation (3), which estimates the effect of criminal justice and public health expenditures on equilibrium drug use without holding drug prices constant. The reduced form equation can be written as:

$\mathrm{Q}_{\mathrm{IJ}}=\pi_{1} \mathrm{PH}_{\mathrm{J}}++\pi_{2} \mathrm{CJ}_{\mathrm{J}}+\pi_{3} \mathrm{X}_{\mathrm{IJ}}+\pi_{4} \mathrm{Z}_{\mathrm{IJ}}+\mu_{\mathrm{IJRF}}$

The coefficients, $\pi_{1}$ and $\pi_{2}$ measure the marginal effect of public health expenditures and criminal justice expenditures on equilibrium drug use. This specification also eliminates the collinearity between drug prices and criminal justice spending and public health spending which is present in the structural demand model.

Four recent empirical studies provide evidence that drug use is responsive to market forces. Saffer and Chaloupka (forthcoming), estimated the effects of cocaine prices, heroin prices and marijuana decriminalization using data from the National Household Survey on Drug Abuse. The results showed a participation price elasticity for cocaine of -.28 and a participation price elasticity for heroin of -.94. Marijuana decriminalization was found to increase the probability of marijuana participation by about 8 percent. Grossman and Chaloupka (1998) used the Monitoring the Future data to estimate the price elasticity of cocaine demand for youth. They used a rational addiction model and found price elasticities ranging from -.6 to -2.4. They also estimated participation elasticities of -.4 to -2.0. Bretteville-Jensen and Sutton (1996) studied the price responsiveness of 500 Norwegian heroin users. The price and consumption data are selfreported. They estimated a price elasticity of heroin demand of -1.23 . A study by van Ours (1995) employed data on opium use in Indonesia during the Dutch colonial period. Opium is pharmacologically similar to heroin. He found a price elasticity of -.7 to -1.0 for use and -.3 to -.4 for participation. 
There are no prior published empirical studies of the effect of criminal justice expenditures and public health expenditures on drug use or related outcomes. There is, however, a simulation study by Caulkins et al. (1997) which estimates the cost effectiveness of enforcement relative to treatment. They find that treatment is more cost effective in reducing drug use than enforcement.

\section{The Data Set}

A data set derived from the 1990 and 1991 National Household Surveys on Drug Abuse (NHSDA) was employed for estimation. This data set consists of over 40,000 observations, which is important since a large sample increases the number of drug users surveyed and the precision of the estimates. The NHSDA are cross-sectional surveys of the US household population aged 12 or older and contain information on socioeconomic characteristics as well as data on drug use. ${ }^{1}$ These surveys exclude residents of non-institutional group quarters (i.e. college dormitories) and exclude residents of institutional group quarters (i.e. prisons). Also excluded are those people with no permanent residence (i.e. homeless and residents in transient hotels). Less than two percent of the population is excluded. The excluded two percent probably have a higher percentage of frequent drug users than the included 98 percent. Although there is no strict dichotomy between occasional and frequent drug users, these surveys are likely to be more representative of occasional drug users rather than frequent drug users. The 1991 survey is over three times as large as the 1990 survey.

The dependent variable is defined as equal to one if the respondent used any illicit drug during the past year and is otherwise equal to zero. A dichotomous variable of this type is usually 
referred to as a measure of drug participation. Drug use is usually defined as a continuous variable measuring a specific quantity over time.

State and local criminal justice spending for drug control, public health spending for drug control and public defense spending related to drug control for 1990 and 1991 were taken from

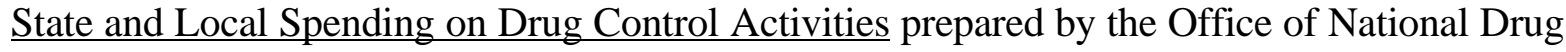
Control Policy (ONDCP), 1993. These data were collected as part of a special survey on drug control done by the US Bureau of the Census. The data estimate expenditures for drug control only. All of these variables were divided by state population since spending is likely to be higher in states with larger populations. These data were appended, by state, to the data taken from the NHSDA.

Criminal justice expenditures include expenditures on police activities, judicial activities, prosecution and corrections. Increased police spending on drug enforcement is expected to have a negative effect on drug participation because of its deterrent aspect and because it increases the number of users who are incarcerated. Judicial activities include the cost of court activities exclusive of prosecution and defense. These expenditures may or may not have a deterrent effect on drug participation. Prosecution includes the cost of attorneys general, district attorneys and other prosecutors. These expenditures may have a negative effect on drug participation to the extent that they increase the probability of conviction. Corrections include the cost of confinement and rehabilitation of those convicted or awaiting trial. This variable may have a negative effect on drug participation if increased corrections expenditures proxy for longer sentences. Correction might also have a negative effect on drug participation since some drug

\footnotetext{
${ }^{1}$ Drug use data from DC were deleted since there were no drug control expenditure data collected from DC.
} 
treatment was also provided by correctional institutions during the sample period. Since the work of the police, judicial, prosecution and corrections programs are linked together, it is also interesting to examine the collective effect of all of these criminal justice expenditures. To do this, the four categories were aggregated to create a single criminal justice expenditure variable.

Public health expenditure includes expenditures on education and treatment. Treatment includes expenditures for hospital facilities directly operated by state or local government and for payments to private facilities. Treatment is expected to reduce drug participation. Education includes expenditures by state and local government for elementary and secondary school drug education and is also expected to reduce drug participation. Since these education expenditures are limited to youth, the effect is expected to be greater for youth.

In addition, a public defense variable was created from the ONDCP data. This variable measures expenditures on legal counsel paid by the court, or paid by government contributions to private legal aid societies and bar associations sponsored programs and the costs of established public defender programs. Increased defense spending may increase drug participation since more resources go into defending users. This reduces the probability of conviction.

Economic theory predicts that the price of illicit drugs is a determinant of drug participation. The ideal price variables for this study would be an index of the price of any illicit drug, the price of marijuana and the price of cocaine. The drugs included in the any illicit drug participation variable are marijuana, cocaine, heroin, psychedelics and a variety of other illicit substances. An illicit drug price index variable should reflect the mix and proportions of these substances. Drug price data, however, are very limited. Only the price of cocaine and the price of heroin are available on a national basis. These data come from the US Department of Justice, Drug Enforcement Agency's STRIDE data set. Drug Enforcement Administration agents and 
police narcotics officers purchase cocaine and heroin regularly. The price, purity, weight and other information are recorded in the STRIDE data set. The procedure described in Saffer and Chaloupka (forthcoming) was followed to estimate state level cocaine and heroin prices. ${ }^{2}$ A state level dichotomous indicator of marijuana decriminalization is also available. Marijuana decriminalization is a law which specifically eliminates criminal sanctions for possession of small amounts of marijuana and eliminates imprisonment for most first offense possession violations. As a proxy for an illicit drug price variable, the price of cocaine, the price of heroin and marijuana decriminalization are included in the regressions. Cocaine prices and heroin prices may be good indicators of the price of any illicit drug since distribution problems are an important determinant of drug prices and these problems tend to be similar for any illicit drug.

Additional economic and dichotomous demographic variables have been defined. These include total personal income from all sources including wages, self-employment, social security, public assistance, child support and other pension income. Income is a continuous variable measured in 1983 dollars. The demographic variables are indicators of age, race, gender and marital status. A variable defined as age and its square are also included to capture differential age effects. A dichotomous variable equal to one if the individual reports that they are Black has been defined. A similar variable was defined for Hispanics. A dichotomous variable equal to one if the individual is male has also been defined. A variable for married has also been defined. There were a number of missing values for this variable. Rather than deleting these observations or omitting this variable, the missing values were estimated. A probit regression using the nonmissing marriage data as the dependent variable with income, age, education, race and ethnicity as

\footnotetext{
${ }^{2}$ These data were appended at the state level since, due to confidentiality requirements, only the individual's state
} 
independent variables was estimated. ${ }^{3}$ This equation was used to predict the values of the marriage variable for the missing observations. A variable measuring sentiment regarding intervention by the state is also included. This variable is defined as the total state government budget divided by the state population. The data on the total state budgets for fiscal 1990 and 1991 were also taken from State and Local Spending on Drug Control Activities. Finally, the regressions include a time dummy variable for 1991. Summary definitions and means of all the variables are presented in Table 1. The means for all variables for a subsample of individuals age 30 or less are also presented in Table 1.

\section{Regression Results}

In each of Tables 2 through 5 there are three probit specifications. ${ }^{4}$ In each table, specification 1 includes total spending on drug control. Specification 2 disaggregates total drug control spending into criminal justice spending, education, treatment and public defense. Specification 3 further disaggregates criminal justice spending into police, court, prosecution, and correction spending and also includes education, treatment and public defense. Tables 2 and 3 are structural demand models while Tables 4 and 5 are reduced form models. Tables 2 and 4 are for the overall population and Tables 3 and 5 are limited to individuals age 30 or less. Estimation of the effects of drug control

of residence was available for the entire data set.

${ }^{3}$ This equation used age, income, education, Hispanic and Black as independent variables. All variables were highly significant. All variables were positive except Black. The regression correctly predicted 73 percent of the known values.

${ }^{4}$ All specifications were also estimated with state dummy variables, non-clustered robust standard errors and with robust standard errors clustered by state. The state dummy variable specifications resulted in considerable collinearity problems. The non-clustered robust standard errors were almost identical to the unadjusted standard errors. The state clustered robust standard errors were in some cases significantly larger than the unadjusted standard errors. These alternative specifications are not presented. 
spending for this age group is interesting since this group has higher participation in illicit drugs than older individuals.

It is important to estimate both the structural demand models as well as the reduced form models since drug prices and drug control expenditures are highly correlated. The structural models include both drug prices and drug control expenditures. Since drug price is assumed to be independent of quantity there is no presumption of endogeneity between price and quantity in estimating this demand model. However, there is collinearity between the drug control variables and the drug price variables which affects the test of significance. The drug control coefficients in the structural demand model estimate the effects of drug control on drug participation, holding drug prices constant. That is, these coefficients represent the effect of drug control programs, exclusive of the indirect effect that these programs have on drug prices. The reduced form model eliminates drug prices by simultaneously solving the structural demand function and the structural supply function for quantity. This eliminates the collinearity problems between drug control and drug prices. The drug control coefficients in the reduced form model include the direct effects of drug control on drug participation and the indirect effects of drug prices on drug participation.

The results for the structural models presented in Tables 2 and 3 show that total drug control spending has a negative and significant effect on drug use. Criminal justice spending is also negative and significant when disaggregated from total drug control spending. When criminal justice spending is disaggregated into four expenditure categories the results are mixed. Police and correction expenditures are significant for both the full sample and the younger sample. Court and prosecution expenditures are each alternately significant in one sample or the other. The two categories of public health expenditure are both insignificant. Defense spending is always positive and significant as expected. The drug prices have the expected sign and are generally significant. Marijuana 
decriminalization is also found to increase drug use. Heroin price is only significant in one specification, but cocaine price is significant in all four specifications. The results for the remaining income and demographic variables are discussed with the results for these variables from the other tables.

The results for the reduced form model presented in Tables 4 and 5 again show that total drug control spending has a significant negative effect on drug use. Criminal justice spending is again negative and significant when disaggregated from total drug control spending. Police and correction expenditures are also negative and significant. Education remains insignificant as in the structural model. The most interesting change from the structural model is in treatment which becomes negative and significant. This may suggest that treatment reduces the number of user-dealers which raises prices and reduces use. Defense spending remains positive and significant as in the structural model. The reduced form model has, in addition, the size of state government variable which is positive and significant in all specifications.

The remaining variables are income and demographic. Income is in general negative in the overall sample, but insignificant in the age 30 or less sample. Illicit drug participation increases with age and then decreases. The results generally indicate that drug participation by Blacks is either lower or about the same as the overall population. Drug participation by Hispanics is lower than the overall population. This study confirms the results found in other studies that illicit drug participation is higher for men and lower for married individuals.

\section{Discussion}

The main findings from the regression results are that overall drug control spending reduces illicit drug participation and that police work and drug treatment are the most important 
drug control programs. The results for police work are consistent with the empirical economic literature on crime which in general concludes that increasing the certainty of arrest is more effective than increasing the severity of the sanction. The results for drug treatment are also consistent with the literature on drug treatment which finds that treatment reduces drug use for both the general population and for individuals in the criminal justice system (ONDCP, 1999). The limited results for drug education may result from the fact that, during the sample period, state spending on drug education was limited to elementary and secondary schools and may also be a result of poorly designed older programs. These problems are being addressed by the newly funded, five year, $\$ 2$ billion multimedia campaign designed to educate youth about drug use.

There are two interesting policy questions which can be examined with these regression results. The first question is: What is the benefit-cost ratio for government drug control? That is, is the marginal dollar value of the social benefits from drug control greater than the marginal expenditure on drug control? The second question is: If social benefits exceed costs, is criminal justice spending more efficient than public health spending?

These questions can be addressed by the assumption that the probability of drug use (the dependent variable) is approximately equal to the number of drug users in the population and by computing the marginal effects of the drug control variables. ${ }^{5}$ The estimated marginal effects are equal to the change in the number of drug users, over population, with respect to drug control expenditures, over population. Since population is in both the numerator and denominator, it cancels out. The marginal effect thus approximates the effect of a unit increase in a drug control spending variable on the number of drug users. The drug control variables are measured in 
thousands of dollars. For example, the marginal effect of criminal justice spending is -.5770 which means that a $\$ 1,000$ dollar increase in criminal justice spending would reduce the number of drug users by .5570 . This can be solved for the amount of added criminal justice spending needed to deter one additional person from using drugs. This value, which is $\$ 1,733$, is convenient to compare with the social benefits of deterring one person from using drugs.

The marginal reduction in drug use from drug control can be estimated with the reduced form models estimated for the overall population and presented in Table 4. These regressions may be the best to use for this exercise since they include the entire population and they include both the direct effect of drug control on drug use as well as the indirect effect of drug control on price, which also affects drug use. To answer the first question, the marginal effect of total drug control spending is estimated from equation 1 in Table 4 . The estimated value is -.2395 . This suggests that an additional expenditure of $\$ 4,170$ on drug control will deter one person from using drugs.

The social costs of drug use were computed by Rice (1990) and are reprinted in Rydell and Everingham (1994) and updated in ONDCP (1999). The Rice calculations include costs of drug use from property destruction, victims of crime, short hospital stays of users, and morbidity and mortality of users. Rice also includes costs from pursuing a criminal career and costs from losing productivity of individuals who are incarcerated. These latter costs are not included in this analysis since the NHSDA only includes individuals who are living at home rather than in prison or who are homeless. The total cost of drug use in 1985 was $\$ 18,427$ million which is equal to $\$ 23,324$ million in 1991 dollars. In 1991, the population of the US age 12 or over was

\footnotetext{
${ }^{5}$ The marginal effects are calculated by multiplying the density function for the equation by the variable's coefficient.
} 
approximately 200 million and 13 percent of the population included in the NHSDA used illicit drugs which is equal to 26 million drug users. With a total cost of $\$ 23,324$ million and 26 million drug users, the social cost of one drug users is $\$ 897$.

The regression suggest that an additional expenditure of $\$ 4,170$ on drug control will deter one person from using drugs. The social cost of a drug user is estimated at about $\$ 897$. That is, the estimated cost of deterring one person from drug use is greater than the cost to society of letting that person use illicit drugs.

These cost calculations must be viewed with some caution since the costs of drug use are inherently difficult to estimate. In addition, the costs and the estimated number of users include both users of marijuana and other illicit drugs. The limited empirical evidence indicates that marijuana is far less costly to society that other illicit drugs. ${ }^{6}$ However, a very large percentage of the estimated total number of drug users, use only marijuana. The result of these caveats is that the $\$ 897$ estimated social cost of drug use is probably more reflective of the social cost of marijuana rather than the social cost of other illicit drug use. The social cost of marijuana maybe somewhat lower than the $\$ 897$ estimate, while the social cost of other illicit drugs maybe much higher than the $\$ 897$ estimate.

The second question regarding whether criminal justice is more effective than public health is somewhat more complicated. The complication, in part, results from the connection between the criminal justice programs. Police spending was found to be a significant deterrent to drug use, but for police work to be effective it must be followed by court, prosecution and in the event of conviction, some type of sanction. The criminal justice variable in specification 2 , in table 4 , 
includes all of these programs. The marginal effect of criminal justice spending is -.5770 which means that $\$ 1,733$ of added criminal justice spending will deter one person from using drugs. The marginal effect of treatment is -.8286 which means that $\$ 1,206$ must be spent on treatment to deter one person from using illicit drugs. This suggests that treatment is more cost effective than criminal justice in deterring drug use. Another complication in this question results from the connection between criminal justice and treatment. Criminal justice and treatment are not necessarily alternative approaches to drug control, and may be combined. The corrections variable is never significant, while treatment is significant. This suggests that a more effective method of reducing drug use might be to direct drug using offenders into a treatment and rehabilitation environment rather than into a prison environment. That is, illicit drug participation might be viewed as more of a public health problem than as a criminal justice problem. According to ONDCP, 1999 the availability of treatment in prisons and through the new drug court system, which provides alternatives to incarceration, has increased since the sample period. A recent report issued by the Arizona Supreme Court (Wren, 1999) concludes that the state saves money by offering convicted non-violent drug offenders probation with treatment, in lieu of prison. The regression results presented in this study also suggest that treatment in place of prison is a cost effective approach to spending the drug control budget.

\footnotetext{
${ }^{6}$ The Drug Abuse Warning Network indicates that for all drug related emergency room visits, only about 10 percent are for marijuana.
} 


\section{References}

Bretteville-Jensen A., and Sutton M., "Under the Influence of the Market: An Applied Study of Illicitly Selling and Consuming Heroin”, Discussion Paper, Centre For Health Economics, University of York, 1996.

Caulkins, J.P., et al. Mandatory Minimum Drug Sentences, Santa Monica CA: Rand, 1997.

Grossman, M., and F. Chaloupka, "The Demand for Cocaine by Young Adults: A Rational Addiction Approach", Journal of Health Economics, 17, 427-474, 1998.

Lee, Li Way, "Would Harassing Drug Users Work?" Journal of Political Economy, vol. 101, 1993.

Office of National Drug Control Policy, State and Local Spending on Drug Control Activities: Report from the National Survey of State \& Local Governments, Washington D.C.: Office of National Drug Control Policy, 1993.

Office of National Drug Control Policy, National Drug Control Strategy Budget Summary, Washington, D.C.: Office of National Drug Control Policy, 1995.

Office of National Drug Control Policy, Reducing Drug Abuse in America, Washington D.C.: Office of National Drug Control Policy, 1999.

Reuter, Peter. "Quantity Illusions and Paradoxes of Drug Intervention: Federal Intervention Into Vice Policy." Law and Contemporary Problems 51(1)Winter, 1988.

Rice, D. P. et al. The Economic Cost of Drug Abuse and Mental Illness, San Francisco, Institute for Health and Aging, University of California, 1990.

Rydell, C. P. and S. S. Everingham, Controlling Cocaine, Rand Drug Policy Research Center: Santa Monica, 1994.

Saffer, H., and F.J. Chaloupka, "The Demand for Illicit Drugs," Economic Inquiry, forthcoming. van Ours, J., "The Price Elasticity of Hard Drugs: The Case of Opium in the Dutch East Indies, 1923-1938", Journal of Political Economics, vol. 103, no. 2., 1995.

Wagstaff, A., "Economic Aspects of Illicit Drug Markets and Drug Enforcement Polices", British Journal of Addiction, 84, 1989.

Wren, C. "Arizona Finds Cost Savings In Treating Drug Offenders”, The New York Times, April, 21, 1999. 
Table 1

Weighted Means from the 1990-1991 National Household Survey of Drug Abuse

\begin{tabular}{|c|c|}
\hline Variables & Definition and Mean \\
\hline $\begin{array}{l}\text { Any Illicit Drug } \\
\text { Participation }\end{array}$ & $\begin{array}{l}\text { A dichotomous variable equal to one if a respondent reports any illicit } \\
\text { drug use in the past year. } \mu=0.130 \mu^{*}=0.231\end{array}$ \\
\hline Total Drug Control & $\begin{array}{l}\text { The sum of spending on police, courts, prosecution, corrections, and } \\
\text { public defense for drug related offenses plus spending on drug } \\
\text { education in secondary schools and drug treatment, as a percent of } \\
\text { state population. } \mu=0.058 \mu^{*}=0.057\end{array}$ \\
\hline Criminal Justice & $\begin{array}{l}\text { The sum of spending on police, courts, prosecution, and corrections } \\
\text { for drug related offenses, as a percentage of state population. } \mu=0.046 \\
\mu^{*}=0.045\end{array}$ \\
\hline Police Spending & $\begin{array}{l}\text { Spending on police for drug control activity, as a percent of state } \\
\text { population. } \mu=0.016 \mu^{*}=0.016\end{array}$ \\
\hline Court Spending & $\begin{array}{l}\text { Spending on courts for drug related offenses, as a percent of state } \\
\text { population. } \mu=0.002 \mu^{*}=0.002\end{array}$ \\
\hline Prosecution Spending & $\begin{array}{l}\text { The sum of spending on prosecution and legal services for drug } \\
\text { related offenses, as a percent of state population. } \mu=0.003 \mu^{*}=0.002\end{array}$ \\
\hline Corrections Spending & $\begin{array}{l}\text { Spending on corrections for drug related offenses, as a percent of } \\
\text { state population. } \mu=0.024 \mu^{*}=0.024\end{array}$ \\
\hline Defense & $\begin{array}{l}\text { Spending on public defense for drug related offenses, as a percent of } \\
\text { state population. } \mu=0.001 \mu^{*}=0.001\end{array}$ \\
\hline Education Spending & $\begin{array}{l}\text { Spending on drug education in secondary schools, as a percent of } \\
\text { state population. } \mu=0.002 \mu^{*}=0.002\end{array}$ \\
\hline Treatment Spending & $\begin{array}{l}\text { Spending on drug treatment, as a percent of state population. } \mu=0.010 \\
\mu^{*}=0.010\end{array}$ \\
\hline $\begin{array}{l}\text { Marijuana } \\
\text { Decriminalization }\end{array}$ & $\begin{array}{l}\text { A dichotomous variable equal to one for states that have eliminated } \\
\text { incarceration as a penalty for most marijuana possession offenses. } \\
\mu=0.312 \mu^{*}=0.305\end{array}$ \\
\hline Real Heroin Price & $\begin{array}{l}\text { Price of one pure milligram of heroin in } 1983 \text { dollars. } \mu=6.222 \\
\mu^{*}=6.265\end{array}$ \\
\hline Real Cocaine Price & $\begin{array}{l}\text { Price of one pure gram of cocaine in } 1983 \text { dollars. } \mu=109.401 \\
\mu^{*}=110.148\end{array}$ \\
\hline Real Income & $\begin{array}{l}\text { Total personal income in thousands of } 1983 \text { dollars. } \mu=11.491 \\
\mu^{*}=7.126\end{array}$ \\
\hline Male & A dichotomous variable equal to one for males. $\mu=0.479 \mu^{*}=0.498$ \\
\hline Marital Status & A dichotomous variable equal to one if married. $\mu=0.573 \mu^{*}=0.299$ \\
\hline Age & A continuous variable measuring age. $\mu=40.846 \mu^{*}=21.537$ \\
\hline Age Squared & Square of Age. $\mu=2026.540 \mu^{*}=494.431$ \\
\hline Hispanic & $\begin{array}{l}\text { A dichotomous variable equal to one if an individual self-reports that } \\
\text { they are Hispanic. } \mu=0.079 \mu^{*}=0.106\end{array}$ \\
\hline Black & $\begin{array}{l}\text { A dichotomous variable equal to one if an individual self-reports that } \\
\text { they are Black. } \mu=0.168 \mu^{*}=0.183\end{array}$ \\
\hline $\begin{array}{l}\text { Size of State } \\
\text { Government }\end{array}$ & $\begin{array}{l}\text { Total state government spending divided by population. } \mu=4.164 \\
\mu^{*}=4.093\end{array}$ \\
\hline Year 91 & A dichotomous variable equal to one for 1991. $\mu=0.502 \mu^{*}=0.497$ \\
\hline
\end{tabular}

Note: Final sample size when missing values were excluded is 35,464 for the complete sample and 22,121 for the sample of ages 30 and less. All data are weighted. *Mean for ages 30 and less. 
Table 2

Structural Demand Function

Illicit Drug Participation in Past Year

\begin{tabular}{|c|c|c|c|}
\hline Sample & \multicolumn{3}{|c|}{ All } \\
\hline Specification & 1 & 2 & 3 \\
\hline Police & - & - & $\begin{array}{c}-4.7524 \\
(-2.52) \\
\end{array}$ \\
\hline Court & - & - & $\begin{array}{c}-19.1512 \\
(-1.22) \\
\end{array}$ \\
\hline Prosecution & - & - & $\begin{array}{c}-24.3705 \\
(-2.55)\end{array}$ \\
\hline Correction & - & - & $\begin{array}{c}-2.7996 \\
(-2.09)\end{array}$ \\
\hline Criminal Justice & - & $\begin{array}{c}-4.6073 \\
(-5.21) \\
\end{array}$ & - \\
\hline Education & - & $\begin{array}{c}-6.4429 \\
(-0.43) \\
\end{array}$ & $\begin{array}{c}-5.7200 \\
(-0.37) \\
\end{array}$ \\
\hline Treatment & - & $\begin{array}{c}0.7823 \\
(0.60)\end{array}$ & $\begin{array}{c}-0.3674 \\
(-0.26)\end{array}$ \\
\hline Defense & - & $\begin{array}{c}105.5828 \\
(4.68)\end{array}$ & $\begin{array}{c}127.8651 \\
(4.97)\end{array}$ \\
\hline Total Drug Control & $\begin{array}{c}-1.7312 \\
(-6.01) \\
\end{array}$ & - & - \\
\hline Decriminalization & $\begin{array}{c}0.1189 \\
(6.04)\end{array}$ & $\begin{array}{l}0.0501 \\
(1.82)\end{array}$ & $\begin{array}{l}0.0654 \\
(2.28)\end{array}$ \\
\hline Real Heroin Price & $\begin{array}{c}-0.0082 \\
(-1.71)\end{array}$ & $\begin{array}{l}-0.0053 \\
(-0.95)\end{array}$ & $\begin{array}{c}-0.0109 \\
(-1.81)\end{array}$ \\
\hline Real Cocaine Price & $\begin{array}{c}-0.0017 \\
(-3.38)\end{array}$ & $\begin{array}{c}-0.0026 \\
(-4.40)\end{array}$ & $\begin{array}{l}-0.0026 \\
(-4.35)\end{array}$ \\
\hline Real Income & $\begin{array}{c}-0.0013 \\
(-1.33)\end{array}$ & $\begin{array}{c}-0.0015 \\
(-1.34)\end{array}$ & $\begin{array}{c}-0.0014 \\
(-1.25)\end{array}$ \\
\hline Age & $\begin{array}{l}0.0698 \\
(21.35) \\
\end{array}$ & $\begin{array}{l}0.0699 \\
(20.02) \\
\end{array}$ & $\begin{array}{l}0.0698 \\
(19.99) \\
\end{array}$ \\
\hline Age Squared & $\begin{array}{l}-0.0011 \\
(-25.20)\end{array}$ & $\begin{array}{l}-0.0011 \\
(-23.53)\end{array}$ & $\begin{array}{l}-0.0011 \\
(-23.50)\end{array}$ \\
\hline Black & $\begin{array}{c}-0.0353 \\
(-1.89)\end{array}$ & $\begin{array}{c}-0.0438 \\
(-2.21)\end{array}$ & $\begin{array}{c}-0.0437 \\
(-2.19)\end{array}$ \\
\hline Hispanic & $\begin{array}{l}-0.2185 \\
(-10.72)\end{array}$ & $\begin{array}{l}-0.2699 \\
(-11.91)\end{array}$ & $\begin{array}{c}-0.2716 \\
(-11.98)\end{array}$ \\
\hline Male & $\begin{array}{l}0.2113 \\
(13.26)\end{array}$ & $\begin{array}{c}0.2202 \\
(12.88)\end{array}$ & $\begin{array}{l}0.2196 \\
(12.84)\end{array}$ \\
\hline Married & $\begin{array}{l}-0.4483 \\
(-22.55)\end{array}$ & $\begin{array}{l}-0.4563 \\
(-21.36)\end{array}$ & $\begin{array}{c}-0.4564 \\
(-21.37)\end{array}$ \\
\hline Year 91 & $\begin{array}{c}-0.0986 \\
(-5.14)\end{array}$ & $\begin{array}{c}-0.0898 \\
(-4.08)\end{array}$ & $\begin{array}{c}-0.0888 \\
(-3.99)\end{array}$ \\
\hline Intercept & $\begin{array}{l}-1.3535 \\
(-16.51)\end{array}$ & $\begin{array}{l}-1.2601 \\
(-12.77)\end{array}$ & $\begin{array}{l}-1.2012 \\
(-11.80)\end{array}$ \\
\hline Number of Observations & 40347 & 35464 & 35464 \\
\hline
\end{tabular}

Note: All specifications are estimated as probit. Standard normal z values are in parentheses. 
Table 3

Structural Demand Function

Illicit Drug Participation in Past Year

\begin{tabular}{|c|c|c|c|}
\hline Sample & \multicolumn{3}{|c|}{ Ages 30 or less } \\
\hline Specification & 1 & 2 & 3 \\
\hline Police & - & - & $\begin{array}{c}-6.4228 \\
(-2.86) \\
\end{array}$ \\
\hline Court & - & - & $\begin{array}{c}-32.3340 \\
(-1.74)\end{array}$ \\
\hline Prosecution & - & - & $\begin{array}{c}-15.7599 \\
(-1.40)\end{array}$ \\
\hline Correction & - & - & $\begin{array}{c}-3.2660 \\
(-2.05)\end{array}$ \\
\hline Criminal Justice & - & $\begin{array}{c}-5.6088 \\
(-5.33) \\
\end{array}$ & - \\
\hline Education & - & $\begin{array}{c}-14.9762 \\
(-0.84)\end{array}$ & $\begin{array}{c}-17.6856 \\
(-0.97)\end{array}$ \\
\hline Treatment & - & $\begin{array}{l}0.2612 \\
(0.17)\end{array}$ & $\begin{array}{c}-0.7511 \\
(-0.45)\end{array}$ \\
\hline Defense & - & $\begin{array}{c}122.8018 \\
(4.63)\end{array}$ & $\begin{array}{c}134.0876 \\
(4.44)\end{array}$ \\
\hline Total Drug Control & $\begin{array}{c}-2.4127 \\
(-6.86) \\
\end{array}$ & - & - \\
\hline Decriminalization & $\begin{array}{l}0.1316 \\
(5.59)\end{array}$ & $\begin{array}{l}0.0569 \\
(1.74)\end{array}$ & $\begin{array}{l}0.0639 \\
(1.87)\end{array}$ \\
\hline Real Heroin Price & $\begin{array}{c}-0.0090 \\
(-1.61)\end{array}$ & $\begin{array}{l}-0.0064 \\
(-0.98)\end{array}$ & $\begin{array}{l}-0.0108 \\
(-1.52)\end{array}$ \\
\hline Real Cocaine Price & $\begin{array}{c}-0.0016 \\
(-2.69)\end{array}$ & $\begin{array}{l}-0.0025 \\
(-3.69)\end{array}$ & $\begin{array}{c}-0.0024 \\
(-3.34)\end{array}$ \\
\hline Real Income & $\begin{array}{l}0.0006 \\
(0.36)\end{array}$ & $\begin{array}{l}0.0003 \\
(0.18)\end{array}$ & $\begin{array}{l}0.0005 \\
(0.28)\end{array}$ \\
\hline Age & $\begin{array}{l}0.3429 \\
(21.68) \\
\end{array}$ & $\begin{array}{l}0.3462 \\
(20.33)\end{array}$ & $\begin{array}{l}0.3455 \\
(20.28) \\
\end{array}$ \\
\hline Age Squared & $\begin{array}{l}-0.0073 \\
(-19.42)\end{array}$ & $\begin{array}{l}-0.0073 \\
(-18.15)\end{array}$ & $\begin{array}{l}-0.0073 \\
(-18.11)\end{array}$ \\
\hline Black & $\begin{array}{c}-0.0568 \\
(-2.54) \\
\end{array}$ & $\begin{array}{c}-0.0632 \\
(-2.65)\end{array}$ & $\begin{array}{c}-0.0602 \\
(-2.51) \\
\end{array}$ \\
\hline Hispanic & $\begin{array}{l}-0.1935 \\
(-8.01)\end{array}$ & $\begin{array}{c}-0.2614 \\
(-9.72)\end{array}$ & $\begin{array}{c}-0.2629 \\
(-9.77)\end{array}$ \\
\hline Male & $\begin{array}{l}0.1639 \\
(8.69)\end{array}$ & $\begin{array}{l}0.1751 \\
(8.67)\end{array}$ & $\begin{array}{l}0.1745 \\
(8.64)\end{array}$ \\
\hline Married & $\begin{array}{r}-0.4216 \\
(-15.47) \\
\end{array}$ & $\begin{array}{l}-0.4286 \\
(-14.63) \\
\end{array}$ & $\begin{array}{r}-0.4296 \\
(-14.66) \\
\end{array}$ \\
\hline Year 91 & $\begin{array}{c}-0.1195 \\
(-5.19)\end{array}$ & $\begin{array}{c}-0.1070 \\
(-4.05)\end{array}$ & $\begin{array}{c}-0.1045 \\
(-3.91)\end{array}$ \\
\hline Intercept & $\begin{array}{l}-4.1081 \\
(-23.05) \\
\end{array}$ & $\begin{array}{l}-4.0367 \\
(-20.27) \\
\end{array}$ & $\begin{array}{r}-3.9833 \\
(-19.75) \\
\end{array}$ \\
\hline Number of Observations & 25066 & 22121 & 22121 \\
\hline
\end{tabular}

Note: All specifications are estimated as probit. Standard normal $\mathrm{z}$ values are in parentheses. 
Table 4

Reduced Form Model

Illicit Drug Participation in Past Year

\begin{tabular}{|c|c|c|c|}
\hline Sample & \multicolumn{3}{|c|}{ All } \\
\hline Specification & 1 & 2 & 3 \\
\hline Police & - & - & $\begin{array}{c}-3.5194 \\
(-1.90)\end{array}$ \\
\hline Court & - & - & $\begin{array}{c}-25.3881 \\
(-1.64)\end{array}$ \\
\hline Prosecution & - & - & $\begin{array}{c}-8.7326 \\
(-0.93)\end{array}$ \\
\hline Correction & - & - & $\begin{array}{c}-0.7949 \\
(-0.61)\end{array}$ \\
\hline Criminal Justice & - & $\begin{array}{c}-2.6825 \\
(-3.38)\end{array}$ & - \\
\hline Education & - & $\begin{array}{c}-11.7304 \\
(-0.80)\end{array}$ & $\begin{array}{c}-14.2527 \\
(-0.96)\end{array}$ \\
\hline Treatment & - & $\begin{array}{c}-3.8523 \\
(-2.43)\end{array}$ & $\begin{array}{c}-4.9296 \\
(-2.50)\end{array}$ \\
\hline Defense & - & $\begin{array}{c}116.8490 \\
(5.47)\end{array}$ & $\begin{array}{c}124.0000 \\
(5.01)\end{array}$ \\
\hline Total Drug Control & $\begin{array}{c}-1.1025 \\
(-2.84)\end{array}$ & - & - \\
\hline Real Income & $\begin{array}{c}-0.0014 \\
(-1.42)\end{array}$ & $\begin{array}{l}-0.0020 \\
(-1.86)\end{array}$ & $\begin{array}{c}-0.0019 \\
(-1.75)\end{array}$ \\
\hline Age & $\begin{array}{l}0.0703 \\
(21.50)\end{array}$ & $\begin{array}{l}0.0707 \\
(20.26)\end{array}$ & $\begin{array}{l}0.0706 \\
(20.24)\end{array}$ \\
\hline Age Squared & $\begin{array}{l}-0.0011 \\
(-25.30)\end{array}$ & $\begin{array}{l}-0.0011 \\
(-23.69)\end{array}$ & $\begin{array}{c}-0.0011 \\
(-23.68)\end{array}$ \\
\hline Black & $\begin{array}{c}-0.0419 \\
(-2.24)\end{array}$ & $\begin{array}{c}-0.0452 \\
(-2.27)\end{array}$ & $\begin{array}{c}-0.0426 \\
(-2.14)\end{array}$ \\
\hline Hispanic & $\begin{array}{c}-0.1871 \\
(-9.31)\end{array}$ & $\begin{array}{l}-0.2650 \\
(-11.74)\end{array}$ & $\begin{array}{l}-0.2657 \\
(-11.77)\end{array}$ \\
\hline Male & $\begin{array}{l}0.2126 \\
(13.35)\end{array}$ & $\begin{array}{l}0.2214 \\
(12.95)\end{array}$ & $\begin{array}{l}0.2209 \\
(12.92)\end{array}$ \\
\hline Married & $\begin{array}{l}-0.4491 \\
(-22.62)\end{array}$ & $\begin{array}{l}-0.4570 \\
(-21.41)\end{array}$ & $\begin{array}{l}-0.4579 \\
(-21.44)\end{array}$ \\
\hline $\begin{array}{l}\text { Size of State } \\
\text { Government }\end{array}$ & $\begin{array}{l}0.0405 \\
(3.14)\end{array}$ & $\begin{array}{c}0.0313 \\
(1.99)\end{array}$ & $\begin{array}{l}0.0374 \\
(2.03)\end{array}$ \\
\hline Year 91 & $\begin{array}{l}-0.0835 \\
(-4.42)\end{array}$ & $\begin{array}{l}-0.0650 \\
(-3.05)\end{array}$ & $\begin{array}{c}-0.0640 \\
(-2.97)\end{array}$ \\
\hline Intercept & $\begin{array}{l}-1.7747 \\
(-28.84)\end{array}$ & $\begin{array}{l}-1.7627 \\
(-25.06)\end{array}$ & $\begin{array}{l}-1.7471 \\
(-21.22)\end{array}$ \\
\hline Number of Observations & 40347 & 35464 & 35464 \\
\hline
\end{tabular}

Note: All specifications are estimated as probit. Standard normal z values are in parentheses. 
Table 5

Reduced Form Model

Illicit Drug Participation in Past Year

\begin{tabular}{|c|c|c|c|}
\hline Sample & \multicolumn{3}{|c|}{ Ages 30 or less } \\
\hline Specification & 1 & 2 & 3 \\
\hline Police & - & - & $\begin{array}{c}-5.3915 \\
(-2.44)\end{array}$ \\
\hline Court & - & - & $\begin{array}{c}-35.9728 \\
(-1.97)\end{array}$ \\
\hline Prosecution & - & - & $\begin{array}{c}-2.1386 \\
(-0.19)\end{array}$ \\
\hline Correction & - & - & $\begin{array}{c}-1.3922 \\
(-0.90)\end{array}$ \\
\hline Criminal Justice & - & $\begin{array}{c}-3.6667 \\
(-3.89)\end{array}$ & - \\
\hline Education & - & $\begin{array}{c}-21.0575 \\
(-1.21)\end{array}$ & $\begin{array}{c}-25.5471 \\
(-1.45)\end{array}$ \\
\hline Treatment & - & $\begin{array}{l}-5.1115 \\
(-2.65) \\
\end{array}$ & $\begin{array}{l}-5.3446 \\
(-2.22) \\
\end{array}$ \\
\hline Defense & - & $\begin{array}{c}132.4842 \\
(5.25) \\
\end{array}$ & $\begin{array}{c}130.7048 \\
(4.49) \\
\end{array}$ \\
\hline Total Drug Control & $\begin{array}{c}-1.9238 \\
(-4.05) \\
\end{array}$ & - & - \\
\hline Real Income & $\begin{array}{c}0.0005 \\
(0.32) \\
\end{array}$ & $\begin{array}{c}-0.0003 \\
(-0.16)\end{array}$ & $\begin{array}{c}-0.00003 \\
(-0.02)\end{array}$ \\
\hline Age & $\begin{array}{l}0.3410 \\
(21.60) \\
\end{array}$ & $\begin{array}{l}0.3465 \\
(20.35) \\
\end{array}$ & $\begin{array}{l}0.3459 \\
(20.31) \\
\end{array}$ \\
\hline Age Squared & $\begin{array}{l}-0.0072 \\
(-19.32)\end{array}$ & $\begin{array}{l}-0.0073 \\
(-18.14)\end{array}$ & $\begin{array}{l}-0.0073 \\
(-18.11)\end{array}$ \\
\hline Black & $\begin{array}{c}-0.0623 \\
(-2.78)\end{array}$ & $\begin{array}{c}-0.0629 \\
(-2.64) \\
\end{array}$ & $\begin{array}{c}-0.0578 \\
(-2.41) \\
\end{array}$ \\
\hline Hispanic & $\begin{array}{c}-0.1584 \\
(-6.67)\end{array}$ & $\begin{array}{c}-0.2550 \\
(-9.53)\end{array}$ & $\begin{array}{c}-0.2561 \\
(-9.57)\end{array}$ \\
\hline Male & $\begin{array}{c}0.1651 \\
(8.77) \\
\end{array}$ & $\begin{array}{c}0.1755 \\
(8.69) \\
\end{array}$ & $\begin{array}{c}0.1748 \\
(8.66) \\
\end{array}$ \\
\hline Married & $\begin{array}{l}-0.4184 \\
(-15.37) \\
\end{array}$ & $\begin{array}{l}-0.4292 \\
(-14.66) \\
\end{array}$ & $\begin{array}{l}-0.4310 \\
(-14.72) \\
\end{array}$ \\
\hline $\begin{array}{l}\text { Size of State } \\
\text { Government }\end{array}$ & $\begin{array}{c}0.0513 \\
(3.22) \\
\end{array}$ & $\begin{array}{c}0.0420 \\
(2.16)\end{array}$ & $\begin{array}{c}0.0405 \\
(1.75)\end{array}$ \\
\hline Year 91 & $\begin{array}{c}-0.1050 \\
(-4.64) \\
\end{array}$ & $\begin{array}{c}-0.0812 \\
(-3.19) \\
\end{array}$ & $\begin{array}{c}-0.0815 \\
(-3.16) \\
\end{array}$ \\
\hline Intercept & $\begin{array}{l}-4.5333 \\
(-27.02) \\
\end{array}$ & $\begin{array}{l}-4.5722 \\
(-24.94) \\
\end{array}$ & $\begin{array}{l}-4.5060 \\
(-23.59) \\
\end{array}$ \\
\hline Number of Observations & 25066 & 22121 & 22121 \\
\hline
\end{tabular}

Note: All specifications are estimated as probit. Standard normal z values are in parentheses. 